\title{
Wat is reformatoriese teologie?: Nadenke na aanleiding van 'n kerklike beswaarskrif
}

\author{
Author: \\ Ignatius W.C. van Wyk ${ }^{1}$ \\ Affiliation: \\ ${ }^{1}$ Africa Institute for \\ Missiology, Reformed \\ Theological College, \\ University of Pretoria, \\ South Africa \\ Correspondence to: \\ Natie van Wyk \\ Email: \\ aim1@mweb.co.za \\ Postal address: \\ PO Box 32186, Waverley \\ 0135, South Africa

\section{Dates:} \\ Received: 29 July 2011 \\ Accepted: 09 Aug. 2011 \\ Published: 04 Nov. 2011 \\ How to cite this article: \\ Van Wyk, I.W.C., 2011, 'Wat \\ is reformatoriese teologie?: \\ Nadenke na aanleiding van \\ 'n kerklike beswaarskrif', \\ HTS Teologiese Studies/ \\ Theological Studies 67(3), \\ Art. \#1156, 11 pages. http:// \\ dx.doi.org/10.4102/hts. \\ v67i3.1156
}

C 2011. The Authors. Licensee: AOSIS OpenJournals. This work is licensed under the Creative Commons Attribution License.

\section{What is Reformational theology?: Thoughts on a petition of protest}

The Netherdutch Reformed Church of Africa (NRCA) has been associated with apartheid for decades. In 2010 the NHKA decided to withdraw its theological legitimisation of apartheid. This decision caused conflict and strife within the church. This article deals with the theological arguments of the opponents of Decision 54 of the General Church Assembly of 2010. It argues that the defenders of apartheid deviate from the Reformational theology on central issues. Special attention is given to the doctrines of justification and the imago Dei. Christian freedom and ethical responsibility also receive attention.

\section{Inleiding}

Die geskiedenis van die Nederduitsch Hervormde Kerk van Afrika (NHKA) hang ten nouste saam met die vryheidstrewe van die Afrikaner (Van Wyk 1994a, 1994b) en die beleid van apartheid (Van Wyk 1978; NHKA 1985, 1990). Gedurende die laaste dekades het ekklesiologie en missiologie in die NHKA hand aan hand met onder meer die volgende gedagtes geloop: onafhanklikheid, selfstandigheid, eie identiteit, selfverwesenliking, geen vermenging en afsonderlikheid (vgl. Van Wyk 1985). Die teologiese gevolg was dat staat, party(e), volk en kerk moeilik onderskei kon word. Die noue band tussen Kerk en volk het uitdrukking gevind in die gedagte van die 'volkskerk' (red. Botha 1989; Van der Westhuizen 1981). Die gebrek aan onderskeidingsvermoë is egter nie net beperk tot die ekklesiologie nie, maar deurtrek die teologiebeoefening van diegene wat hulle enduit vir die apartheidsideaal beywer. Hierdie benadering het aanleiding gegee tot twee fundamentele teologiese probleme, naamlik die verknogtheid van die teologie aan 'n ideologie en die onvermoë om aan die Reformatoriese onderskeidings van geloof en werke, regverdiging en heiliging, dogmatiek en etiek, en belydenis en utopie reg te laat geskied. Hierdie twee teologiese dwalings het die gevolg gehad dat Besluit 54 van die 69ste Algemene Kerkvergadering ${ }^{1}$ tot sodanige protes gelei het dat 'n buitengewone Algemene Kerkvergadering op 04 en 05 Oktober 2011 byeengeroep moes word. Die protes van 'n minderheidsgroepering in die NHKA het uitgemond in hulle 'Beswaarskrif'(2010). (Vervolgens word gewoon na 'Beswaarskrif' verwys en na die opstellers hiervan as 'Beswaardes'. Vir inligting oor die Kommissie van die AKV se hantering van die saak kyk Beukes [2011]; kennisgewing en konsepagenda in Die Hervormer [2011c]; en die redes vir die AKV in Die Hervormer [2011d]).

Hierdie artikel is 'n kort kursus oor die teologiese vertrekpunte in die Reformatoriese teologie. Die teologiese standpunte van Luther en Calvyn hieronder aangebied sal dit duidelik laat blyk dat die 'Beswaardes' nie daarop aanspraak kan maak om geloofwaardige verdedigers van die Reformatoriese leer te wees nie. Met 'Beswaardes' word bedoel die opstellers en ondertekenaars van die beswaar teen Besluit 54 asook die simpatiserende briefskrywers. Ek fokus op die teologieverstaan agter hulle beswaar. Hulle beskuldig die Kerk van kettery, maar hulle eie teologie getuig van 'n afwyking van die sentrale motiewe van die hoofstroom van Reformatoriese denke.

Die artikel is nie 'n poging om die redes vir Besluit 54, soos deur die 'vyf dosente' voorgedra, te verdedig nie. 'n Besluit van 'n Algemene Kerkvergadering word nie nét of hoofsaaklik op grond van 'n voorstel in die agenda geneem nie, maar op grond van die aanloop van die saak en die bespreking tydens die vergadering. Die teologie van die 'vyf dosente' wat die motiveringsgedeelte van die voorstel geskryf het is na my mening irrelevant aangesien die besluit die Kerk se besluit is. Die artikel wil eerder op die groter probleem, naamlik die basiese argumentasiestruktuur

1.Die 69ste Algemene Kerkvergadering maak in die lig van die 68ste Algemene Kerkvergadering se besluit dat dit verkeerd was om ' $n$ bepaalde regeringsbeleid (apartheid) goed te praat, onomwonde die uitspraak dat apartheid nie teologies geregverdig kan word nie. Die Kerk ver Die Kerk verwerp sy goedkeuring van apartheid omdat dit (1) in stryd is met die evangelie van Jesus Christus, (2) gebaseer is op die diee Christus wat vanie Christus wat van ons eis om met ander deernis te hê soos God met ons deernis het. Daarom kan ons die apartheidsisteem in kerk en samelewing nie anders as inherent mensonterend sien nie. Terwyl die aantasting van menswaardigheid op geen manier Bybels, teologies of moreel geregverdig kan word nie, dring die evangelie sowel mense wat deur onregverdige strukture bevoordeel is as die wat nie bevoordeel is nie, om sulke regverdigingspogings te weerstaan (NHKA 2010:108-109). 
van die Beswaarskrif konsentreer. Die argument kom op die volgende neer: Die aanhangers van apartheid is in ooreenstemming met die regte Reformatoriese leer terwyl diegene wat apartheid verwerp 'n leerdwaling begaan. Die loskoppeling van die Hervormde Kerk van apartheid is rewolusionêr en kan verklaar word met die feit dat die Kerk die 'bevrydingsteologie', die 'teologie van die revolusie' en die 'Belhar Belydenis' (Beeld 04 Junie 2011a:3, 08 Junie 2011b:4) omarm het. Die Beswaardes verwag van die Kerk om die 'regte Reformatoriese leer', soos dit in die verlede in die NHKA geleer is, te bly handhaaf - en daarmee saam die sosiaal-etiese oordeel wat daarmee gepaard gegaan het. Die Beswaardes het dan ook reeds laat blyk dat hulle bereid is om finansiële afpersing en hofdreigemente in te span om die Kerk te dwing om húlle etiese oordele oor sosiaal-politieke aangeleenthede te aanvaar (kyk Beukes 2011; Beeld 04 Junie 2011a:3, 08 Junie 2011b:4). Juis hierdie hanteer van sake wys dat daar agter die Beswaarskrif 'n onreformatoriese teologie lê wat gedy op gewetensdwang en die onvermoë om tussen dogmatiek en etiek te onderskei.

Die artikel wil ook die samehang tussen geloof en werke, regverdiging en liefde, en antropologie en sosiale etiek beredeneer. Die Reformatoriese dissonansie van die Beswaardes kom tot uiting in die redenasie dat Christene, geskape na of in die beeld van God, geen morele verantwoordelikheid in hierdie wêreld het nie aangesien die sondaar net op verlossing moet hoop. Die probleem met hierdie argument van sonde en verlossing (en verder niks nie), is dat die samelewing bloot aan die apartheidsideaal oorgelaat moet word. Op hierdie wyse kom mens in die vaarwaters van die fatalisme, Gnostisisme en dosetisme.

In die artikel word ook op die vraagstuk van verandering in ons teologiese denke gekonsentreer. Die problematiek van tradisie en vernuwing word aangespreek aangesien die Beswaardes daarop aandring dat die Kerk by haar tradisionele menings oor sosiaal-etiese sake moet bly. Uit respek óf vrees vir die voorvaders moet daar ten alle koste by die menings van die verlede gebly word, en só word ons verhinder om die uitdagings van die eie tyd aan te pak.

\section{Kom ons begin voor!}

Die Beswaarskrif, en die uiteindelike noodsaak om 'n buitengewone algemene kerkvergadering byeen te roep, dwing die Hervormde Kerk om duidelikheid te kry oor die kernsake van die Christelike geloof en die teologiese nadenke oor die Bybelse boodskap. Aangesien die Beswaardes (Beswaarskrif 2010:7) beweer dat die besluit van die Hervormde Kerk om haar teologiese legitimering aan apartheid te onttrek op 'n leerdwaling neerkom wat deur 'n ideologie aangedryf word, is dit noodsaaklik dat ons juis nóú weereens duidelik sal uitspel wat die regte Reformatoriese leer is en wat nie. Om hierdie rede meen ek dat dit noodsaaklik is om opnuut te gaan kyk wat die kerkhervormers oor die kernsake van die teologie geleer het; want dit is dáár waar die meningsverskil en onkunde lê.

\section{Die onderwerp van die teologie}

Volgens die Beswaarskrif is die onderwerp van die teologie die 'radikaal sondige mens en die verlossing deur Christus' (Beswaarskrif 2010:7). Natuurlik is hierdie stelling nie verkeerd nie, maar dit volg nie die voetspore van die eerste en tweede geslag Reformatore nie. Die grondleggers van die Reformasie het, om redes wat hieronder duidelik sal word, 'n ander skema gevolg. Volgens die Reformatoriese teologie is die eintlike teologiese vraag: Wie is God, en wie is die mens voor die aangesig van God? Dit is 'n forensiese vraag wat met God se oordeel oor ons menswees te make het (Jüngel [1998] 1999:174-180). Luther ${ }^{2}$ het daarom teologiebeoefening soos volg saamgevat:

Die kenmerkende onderwerp van die teologie is die mens, wat aan die sonde skuldig en daaraan onderworpe is, en God, wat die sondige mens regverdig en red. Wat buite hierdie onderwerp om in die teologie nagevors en bevorder word, is dwaling en gif.

(WA 40/II, 328, 17-20 = Enarratio Psalmi LI - 1538, [outeur se eie vertaling])

Die hart van die Reformatoriese teologie is daarom die regverdigingsleer. Luther het in 1537 (WA 39/1, 205, 2) gesê:

Die artikel van die regverdiging is die meester, vors, heer, rigtinggewer en regter oor allerlei leeraangeleenthede. Dit bewaar en stuur die kerklike leer in die regte rigting en skerp ons gewete op voor God. Sonder hierdie artikel is die wêreld niks anders as dood en duisternis nie.

(WA 39/1, 205, 2 - 1537, [outeur se eie vertaling])

Op grond van hierdie en ander uitsprake van Luther is die klassieke uitdrukking articulus stantis et cadentis ecclesiae [die artikel is waarmee die kerk staan en val] geskep. In die vorige eeu het Calviniste soos Ernst Wolf wat die kerklike teologie van ideologiese gevangeskap wou bevry, gesê dat hierdie artikel die 'middelpunt en grens' van alle teologie is (Jüngel [1998] 1999:13). Ten spyte van hierdie uitsprake was daar nie altyd binne die Barthiaanse tradisie (Jüngel [1998] 1999:15-26), insluitende die NHKA, ${ }^{3}$ dieselfde waardering vir die regverdigingsleer nie. Die situasie is egter vinnig besig om binne die Gereformeerde wêreld te verander (vgl. Weinrich \& Burgess 2009; Busch 2010).

Daar is goeie redes hoekom ons by die regverdiging, en nie die verlossing ${ }^{4}$ moet begin nie. Ons lewe nie net voor die aangesig van God (coram Deo) nie, maar ook voor die aangesig van die wêreld (coram mundo). As mens word jy nie net tot verantwoording geroep deur God nie, maar ook deur die wêreld. Daar is aanhoudend een of ander instansie wat ons tot verantwoording roep. Ons moet rekenskap gee hoekom ons dinge op 'n bepaalde wyse doen en bepaalde menings huldig. Ons leef in 'n vertribunaliseerde wêreld

2.Ek neem verantwoordelikheid vir alle vertalings.

3.Min mense in die NHKA steur hulle aan die regverdigingsleer. Die waan bestaan dat die gestoei met sin en betekenis die eintlike saak van die geloof is. Gerhard Saute (1982, kyk ook 2011:95-114) het aangetoon dat die 'sin-soekery' van die eietydse Protestantisme moeilik met die regverdigingsleer versoenbaar is. Dít beteken Protestantisme moeilik met die regverdigingsleer vis (2009) tereg uitwys.
(a) van die sinvraag ontduik moet word nie, soos Vroom

4.Verlossing uit die bose wêreld is ' $n$ belangrike aspek van die evangelie (Gal 1:4, Rom 7:24, Matt 6:13) en spesifiek die eskatologie. Die polemiek is gerig teen die antropologiese dosetisme en die versaking in die etiek wat kenmerkend van 'n fatalistiese lewenshouding is (vgl. Wolf 1975). 
(Bayer 1984:9-15). Ons is aanhoudend voor gerig. Ons word uitgedaag om onsself te regverdig in die lig van die sosiaal-etiese verwagtinge binne die sekulêre wêreld. Ons word gemeet aan ons doen en late asook ons opinies en menings. Die gevolg is dat ons permanent, in die oё van bepaalde mense, tekort skiet. Ons voldoen nie aan die verwagtinge nie. Ons word daarom nie net geoordeel nie, maar dikwels ook veroordeel - veroordeel omdat ons volgens die verwagtingspatroon van bepaalde groeperinge misluk. Maar, ons almal wil erkenning geniet en is daarom aanhoudend besig met een of ander poging om erkenning by ander af te smeek. Hierdie erkenning kry ons dan meestal slegs vanaf 'n paar mense. So trek ons onsself terug in 'n eie klein wêreldjie waar die oordele oor ons menswees positief mag klink. En juis dít is die probleem. Ons verlaat ons op een of ander vorm van morele rigorisme wat ons dan met 'selfverwesenliking' verwar. Die uiteinde? Ons dink ons kan op ons eie 'n gelukkige wêreldjie skep. Ons handelinge, die moraal en die wet word dan die allesbepalende. Nou weet ons dat ons nie aan die verwagtinge voldoen nie. In die oë van ander bly ons bedenklike mense (Jüngel 1990a:196-199, 1999:3-6). Die enigste uitkomkans uit hierdie bose kringloop is om ons menswees nie deur ons handelinge en ander se oordele daaroor te laat definieer nie maar deur God se oordeel ${ }^{5}$. Gelukkige menswees het dus met die geregtigheid van God te make. Die 'geregtigheid van God' is nie die geregtigheid waarmee Hy geregverdig kan word nie, maar die geregtigheid waarmee Hy ons regverdig verklaar (iustitia dei, non qua ipse iustus est, sed qua nos iustus facit; Jüngel 1990b:350). God se geregtigheid is daarom 'n Genetivus auctoris - die daad van sy regsprekende geregtigheid oor ons as mense wat misluk om 'n regverdige wêreld te skep.

Laat ek dit kontekstueel verwoord. Ons meen dat dit wat ons tot stand kan bring ons menswees bepaal. Ons glo daarom dat ons primêr skeppers is. Die apartheidsbestel was een van ons maaksels. Sommiges wil nou enduit ander dwing om dít positief te waardeer. Ons wil op hierdie wyse vashou aan die werke van die verlede. Ons wil erkentlikheid daarvoor afdwing deur te doleer en hof toe te gaan. Die feit is dat ander hierdie werke nie gaan prys nie. Ons eie goeie oordeel oor hierdie produk gaan niks verander aan die negatiewe oordele van ander nie. Met die verdere verloop van tyd gaan die oordeel van die geskiedenis oor ons en ons produk net al hoe meer verdoemend word, in dié opsig dat die belangstelling om iets positief hieroor te sê heeltemal gaan taan. Met ander woorde: Tans kan mens geen goeie oordeel oor apartheid in kerkgeskiedenisboeke lees nie ${ }^{6}$. Binnekort sal daar niks meer oor hierdie ideaal geskryf word nie. En moet ons nou die Kerk verwoes ter wille van hierdie verlore saak?

5.Die Beswaardes en hulle geesgenote (vgl. Van den Berg 2011:6) maak die fout deur te dink dat ons die morele integriteit van ons voorvaders deur sinodebesluite kan beskerm. Die wreed heid van die lewe het te make met die feit dat ons, as sondaars, beskerm. Die wreedheid van die lewe het te make met die feit dat ons, as sondaars, uitgelewer is aan die oordele en veroordelings van ander. Hierteen staan ons almal, insluitende ons voorouers, magteloos. Die enigste oplossing is om jou op die

6.Die monumentale werk van MacCulloch (2009:980-985) bevat nog 'n paar negatiewe Die monumentale werk van MacCulloch (2009:980-985) bevat nog 'n paar negatiewe
opmerkings oor hierdie projek. Gaan die volgende groot kerkgeskiedenisboek nog 'n voetnota oor apartheid bevat?

\section{Regverdiging en die onderskeiding tussen persoon en werke}

Die 'Reformatoriese wending' in Luther se teologie het te make met sy ontdekking dat daar tussen wet en evangelie onderskei moet word. Hierdie onderskeidingsvermoë is waaroor die Reformatoriese teologie handel. Hierdie vermoë om tussen wet en evangelie te onderskei maak volgens Luther van iemand 'n ware teoloog (Bayer 2003:41-44). Terugskouend het hy eenmaal tydens ' $n$ tafelgesprek gesê:

Vantevore het ek niks kortgekom nie, behalwe dat ek geen onderskeid tussen wet en evangelie kon maak nie, beide vir dieselfde saak aangesien het en gemeen het dat Christus Hom van Moses slegs in historiese afstand en graad van volmaaktheid onderskei. Maar toe ek hierdie onderskeiding ontdek het dat die een die wet en die ander een die evangelie is, het ek [teologies] deurgebreek.

(WA TR 5, 210, 12-16, [outeur se eie vertaling])

In sy nuwejaarspreek oor Galasiërs 3:23-29 van 1532 sê hy:

Die heilige Paulus se mening is dat daar in die Christendom, sowel deur die predikers as die toehoorders, 'n duidelike onderskeid geleer en gemaak sal word tussen wet en evangelie, werke en geloof ... aangesien hierdie onderskeiding tussen wet en evangelie die hoogste kuns in die Christendom is. Almal wat hulle beroem op die naam 'Christen', óf hierdie naam wil aanneem, moet [hierdie onderskeiding] kan maak. Waar daar 'n gebrek is aan hierdie vermoë, kan mens 'n Christen nie van 'n heiden of 'n Jood onderskei nie - só fundamenteel is hierdie aangeleentheid.

(WA 36, 25, 17-26, [outeur se eie vertaling])

Dit is belangrik dat ons sal begryp dat hierdie perspektief te make het met een van die kernprobleme agter die Beswaarskrif. 'Wet' het nie net met die Tien Gebooie te make nie, maar met die poging van die mens om eerbaarheid en erkenning te verwerf deur sy wêreld goed gestalte te gee. Luther het besef dat dít nie suksesvol gedoen kan word nie, aangesien ons aanhoudend hierin misluk (sondaars is). As mense moet ons dus ' $n$ ander benadering tot die lewe ontwikkel. Hierdie benadering het met die kuns te make om te onderskei tussen die persoon en die werke van die persoon.

Luther (WA 39/1, 283, 9 = Zirkulardisputation de veste nuptiali - 1537) het by geleentheid die volgende insiggewende uitspraak gemaak: 'die werk watek doen maak nie die persoon nie, maar die persoon wat ek is, maak die werk' (opus non facit personam, sed persona facit opus). Hiermee bedoel hy dat ons menswees nie deur ons pogings tot selfverwesenliking bepaal word nie, maar dat ons as (Christen)mense nogtans op 'n verantwoordelike wyse gestalte aan die lewe moet gee. Hy (WA 1, 226, 8 = Disputatio contra scholasticam theologiam - 1517) het as ' $n$ jongman hierdie saak nog skerper geformuleer: 'Ons word nie geregverdig deurdat ons die regte doen nie, maar as geregverdigdes doen ons die regte dinge' (Non efficimur iusti iusta operando, sed iusti facti operamur iusta). Eietyds gesê: As mense wat deur die geloof tot gerespekteerde persone gemaak word (fides facit personam; WA 39/1, 283, 1), as mense wat dus nie op grond van hulle sosiale projekte respek wil afdwing nie, word ons bevry om daagliks opnuut te soek na 
die menslik aanvaarbare, sonder dat ons totale menswees daarvan sou afhang. Daarmee wil ons saam met Luther sê dat ons menswees nie afhang van die positiewe oordele van ander oor ons strewe na selfverwesenliking nie, maar dat ons op God se finale oordeel wat genadig en barmhartig is, steun. Ons kan nie staatmaak op die positiewe oordele van ander nie, aangesien ons as mense faal en misluk. Mense gaan nie ons verkeerde dinge goedpraat nie. Om hierdie rede moet ons altyd van vooraf begin soek na die regte en die goeie. Gelowiges kan dit juis doen aangesien ons uit dankbaarheid lewe. Dankbaarheid vir die verlossing van futiele pogings tot selfverwesenliking en die afdwing van goeie woorde deur ander, stel ons in staat om daagliks opnuut te dink wat reg en goed sou kon beteken.

\section{Die samehang van regverdiging en werke}

In die filosofiese etiek geld sedert Aristoteles dat iemand geregverdig word of as 'n moreel-aanvaarbare mens beskou word deurdat hy regverdig handel of moreel goeie dinge doen (iusta operando iusti efficimur, vlg. Jüngel 1990b:351). Luther (WA 56, 255, 18-19 = Voorlesing oor Romeine $1515 / 16)$ stel die teendeel: 'omdat ons regverdig gemaak word, doen ons die regte, ons word nie regverdig deurdat ons die regte doen nie' (non enim iusta operando iuisti efficimur, sed iusti fiendo et essendo iusta operamur). Waaroor daar geen misverstand moet wees nie is dat Christene goeie en regte dinge moet doen. Christene word nie van morele plig onthef omdat hulle geregverdig en verlos word nie. Die Calvinistiese konsep van regverdiging en heiliging het dít baie duidelik uitgewerk (vgl. Burgess 2009). Dit is onder meer op hierdie punt waar die Beswaarskrif afwyk van die Reformatoriese teologie. Deur die Kerk van 'horisontalisme en oppervlakkige bevrydingsteologie' ${ }^{\text {'7 }}$ te beskuldig omdat sy 'n teologiese uitspraak gemaak het met sosiaal-etiese konsekwensies, is in beginsel 'n afwyking van die Reformatoriese teologie. Reformatoriese teologie gaan nie net om die regte onderskeiding van geloof en werke, regverdiging en heiliging, dogmatiek en etiek nie, maar ook om die regte samehang van die twee pole. Die tema waar hierdie samehang die beste na vore tree is die Christelike vryheid.

\section{Christelike vryheid en die samehang van regverdiging en etiek}

Die regverdigingsleer, as die hart van die 16de-eeuse Reformasie, is vryheidsleer (Körtner 2010:51). By Luther (WA 6, 538, 30 = De captivitate Babylonica ecclesiae praeludium -1520) leer ons dat teologie wetenskap van die Christelike vryheid (scientia libertatis Christianae) is. Hoe Luther vryheid verstaan, vind ons klassiek uitgedruk in die volgende twee stellings van sy vryheidsgeskrifte: "'n Christenmens is 'n vrye heer

7.Die Beswaarskrif (2010:4) stel: 'Die stelling dat apartheid in stryd is met die evangelie van Jesus Christus, is in stryd met die uitgangspunte van die Bybels-Reformatoriese teologie soos saamgevat in die Belydenisskrifte van die Hervorming ... Die evangelie en dood. Die oormatige klem op die horisontale spreek van ' $n$ oppervlakkige en dood. Die oormatio.

8.Daar bestaan Duitse en Latynse weergawes van sy Vryheid van ' $n$ Christenmens wat inhoudelik hier en daar verskil. Die twee weergawes is opeenvolgend in die WA afgedruk. Kyk na Jüngel (2000) vir breedvoerige inligting oor hierdie geskrif. oor alle dinge en niemand se onderdaan nie. 'n Christenmens is ' $\mathrm{n}$ diensbare kneg van alle dinge en elkeen se onderdaan' (WA 7, 21, 1-4 = Von der Freiheit eines Christenmenschen 1520a):

Die mens leef nie net vir homself in hierdie sterflike liggaam, om in hom te werk nie, maar ook vir alle mense op aarde; ja hy leef vir ander en nie net vir homself nie ... Kyk, dít is in der waarheid 'n Christelike lewe waar die geloof deur die liefde werksaam is; met ander woorde dit is ' $n$ lewe wat met vreugde en liefde besig met die werksaamheid van vrye knegskap waardeur hy die andere met graagte uit vryheid dien met.

$(W A 7,64,15-36=$ Tractatus de libertate christiana $1520 b$, [outeur se eie vertaling])

Luther se stelling oor die vryheid is bloot ' $n$ ander formulering van Christus se dubbele liefdesgebod (Mark 12:29-31). Liefde vir God en liefde vir die naaste beteken vryheid van beheersing deur afgode en vryheid om selfs jou vyand lief te hê. Gedagtig aan die argument van die Beswaarskrif, word daar in wat volg op die tweede gedeelte van Luther se stelling gekonsentreer.

Volgens Luther hang die Christelike geloofsvryheid onlosmaaklik met diensbaarheid en naasteliefde saam. Die geloof in Christus stel jou vry om diens te lewer aan jou medemens. Dít noem mens liefde, en liefde moet nóú, hiér op aarde beoefen word.

Laat ek die argument eers onderbreek om hier iets oor Christus ${ }^{9}$ self te sê. Daar moet onthou word dat Luther self met die onderskeiding van Christus as gawe (donum) en as voorbeeld (exemplum) gewerk het. In lyn met die res van sy teologie het hy die twee motiewe nooit geskei nie. Hy self sou argumenteer dat Jesus nie tot 'n blote voorbeeld verlaag mag word nie, want dit sal die teologie inderdaad verlaag tot plat moralisme. Maar, Christus ís ook voorbeeld vir die morele lewe. As Christus nie ons voorbeeld is nie, sal iemand anders dit wees (WA 7, 58, 31). Hy sê daarom tereg in een van sy postilles:

Christus as gawe voed jou geloof en maak van jou 'n Christen. Maar, Christus as voorbeeld inspireer jou in jou werke. Dít maak nie van jou 'n Christen nie, maar dit gaan uit van dít wat reeds van jou 'n Christen gemaak het. Gawe en voorbeeld is net so ver van mekaar geskei as geloof en werke. Die geloof het niks uit sigself nie; slegs Christus se werk en lewe. Die werke hét egter iets van 'n eie waarde; maar nou nie vir jouself nie, maar vir jou naaste.

(WA 10/I, 12, 17, [outeur se eie vertaling])

Calvyn volg Luther in hierdie argumentasie deur ook te stel dat Christus nie net verlosser is nie, maar ook voorbeeld (Inst 3. 6. 3). Hy neem die navolging egter 'n stap verder deur die gelykvormigheid aan Christus te verbind aan die bereidheid tot martelaarskap (Inst 3. 9. 6).

Hoe is dit moontlik om in hierdie wêreld (en veral in hierdie land) liefde te beoefen? Christene is vry om liefde te beoefen, aangesien die oorsprong van hulle moraal in die geskenkte

9.Lees ek reg, verstaan die Beswaardes Christus as die verlosser van die sonde, of eintlik uit hierdie bose wêreld uit - en verder niks? Op hierdie wyse word daar 'n streep getrek deur die tweede tafel van die wet. 
vryheid van die geloof lê. Wat aan ons verkondig word, naamlik die belofte van regverdigverklaring, stel ons vry om goed en reg in hierdie wêreld te handel. Die Christelike liefde is moontlik aangesien dit genadiglik en hoogstens antwoord is op die evangelie wat ons telkens nuut hoor. Christelike etiek is nie 'n buig voor 'n onveranderbare wetlike verpligting of ideaal nie, maar die vrye antwoord op die Woord wat vryheid skep deur die verkondiging daarvan (Bayer 1995:1-5). Die implikasie hiervan, behoort vir die NHKA duidelik te wees ${ }^{10}$.

Die probleem met die Beswaarskrif is dat, omdat daar uitsluitlik met verlossing en nie ook met regverdiging gewerk word nie, die etiek opgehef word ten gunste van 'n sosiale utopie $^{11}$. Die morele en etiese verantwoordelikhede van die kerk word afgemaak, terwyl die welwese van hierdie land, onwrikbaar en twyfelloos van één sosiaal-politieke model afhanklik gemaak word. Anders gestel, meen die Beswaardes die Christelike boodskap gaan net oor sonde en verlossing. Christene het geen etiese verantwoordelikheid ten opsigte van die samelewing nie, maar verwag terselfdertyd dat dit bloot aan die apartheidsideaal oorgelaat moet word. En wie hiervan verskil, word van kettery beskuldig.

Luther het al geweet dat utopie en rasionaliteit twee grondtrekke van menswees is. Die mens is volgens 'n rasionele wese met' $n$ hart wat die (volmaakte) wil skep (animal rationale, habens cor fingens) (WA 42, 348, $38=$ Komm oor Genesis 8:21 - 1536). Die skeptisisme van die geloof verwag egter van ons om beskeie te wees oor ons skeppingsvermoë. Daarby behoort ons, in die lig van die eindoordeel, te weet dat daar hoogstens begrensde pogings van ons verwag word. Die Reformatoriese etiek is dus moeilik versoenbaar met'n moraal wat uit 'n utopie gevoed word. Dit is veel eerder versoenbaar met die gedagte van verantwoordelikheidsetiek ${ }^{12}$. Trouens, Luther (WA 20, 59, 13-60 = Komm oor Prediker 3:1 - 1526) het geleer dat mens moet wegbly van die begeerte na die perfekte toekoms (concupiscentia futurorum). Matigheid is die gepaste lewenswyse in ons gebrekkige wêreld. Die gryp na die ideale toestand maak net korrup. Die Lutherse etiek maan voortdurend om nugter en saaklik te bly, om te soek na relatiewe verbeteringe en om in nederigheid voor God verantwoordelikheid te neem vir elke dag se nuwe uitdaging (Ebeling 1972; Honecker 1990:327-337, 1995:15-41). Etiek in die Reformatoriese tradisie is daarom 'konflikwetenskap' (Bayer 1995:184). Te midde van die onvolmaakte stry dit vir die waarhede van die evangelie. Te midde van boosheid en onmenslikheid word die voetspore van Jesus gevolg sodat

10.Apartheid (en alles wat daarmee saamgaan) is in die verlede as ' $n$ 'onveranderlike beginsel' gesien (NHKA 1973; vgl. Van Wyk 1978:261). Vandag word dit deur die Beswaardes as ' $n$ onopsegbare ideaal gesien. Hulle belas hulle self met morele dwang om hierdie ideaal nie prys te gee nie. Die verpligting om daarvoor te bly veg beroof hulle van vryheid en gelatenheid. Die verknogtheid aan ' $n$ utopie verlei tot fanatisme wat nie by gelowiges pas wat veronderstel is om vanuit die vryheid te lewe nie.

11.Apartheid is nie net ' $n$ ideologie (konsentreer nét op sekere aspekte van die werklikheid) nie, maar ook 'n sosiale utopie (verwag die perfekte toekoms; vgl. Beswaarskrif 2010:5)

12.Die Reformatoriese etiek is moeilik versoenbaar met die utopiese denke van byvoorbeeld Ernst Bloch. Dit is veel eerder versoenbaar met die verantwoordelikheidsetiek van Max Weber, Hans Jonas en Walter Schulz (Bayer 1995:182-196). Volgens my steun die Beswaardes ook op die utopie en verwaarloos rasionaliteit en die gewete. daar binne die huisgesin, kerk, staat en ekonomie menslik en vreugdevol gelewe kan word (Bayer 1995:199-246; Bühler 2009). Gelatenheid, geduld en toleransie (Ebeling 1983) is die kenmerke van diegene wat hierdie weg volg.

Die Beswaarskrif pretendeer om die regte leer te beskerm, maar ironies genoeg mond dit uit in 'n stuk ongeduldige moralisme. Moraliste weet altyd beter, is altyd reg en wil aan ander, selfs met dwang, voorskryf. Die Protestantse vryheid wat tot uiting kom in die 'priesterskap van alle gelowiges' word deur die Beswaarskrif negeer. 'n Bepaalde klerikale klas meen dat hulle en hulle alleen weet wat goed is vir hierdie land. Hierdie klerikaliste maak van hulle self moraal-ikone wat hulle saak medialiseer en dramatiseer. Hulle aanspraak op absolute kennis van goed en kwaad gaan gepaard met 'n aanhoudende populistiese vereenvoudiging van komplekse politieke sake wat retories, herhalend, op ander afgeforseer word. Met 'regte leer' het dít niks te make nie (vgl. Graf 2011:69-72 vir die soortgelyke tendens in Duitsland).

Die gewetensdwang (weerhouding van offergawes en hofdreigemente ${ }^{13}$ ) waarmee die Beswaardes die Kerk afpers, getuig daarom van 'n moraliteit en 'n benadering wat niks met Reformatoriese teologie te make het nie. Trouens, dit het niks met die Nuwe Testament te make nie (vgl. bv. Paulus se argument oor die offervleis in 1 Kor 10:24-33).

In die lig van bogenoemde is dit op hierdie punt belangrik om iets oor die Christelike gewete te sê. Die Christelike gewete is geen bewussynsfenomeen nie en word ook nie deur wêreldlike fenomene bestem nie, maar deur Christus en die geloof in Hom. Om hierdie rede is die Christelike gewete 'n vrye gewete en word mense aangemoedig om in vryheid teenoor die afgode van die hart te lewe (conscientia liberata est, in die quod abundantissime est liberari - WA 8, 575, 27). Omdat ons nie net coram Deo lewe nie, maar ook coram hominibus, moet ons besef dat ons die burgerlike verantwoordelikheid het om hierdie lewe menslik gestalte te gee. Vanselfsprekend is die riglyne van die wet van God belangrik vir gelowiges. Ons gewete of aanvoeling van wat billik en goed is, is nét so belangrik. Die Christelike gewete word nie van die menslike rede geskei nie. Gewetensbeslissings gaan met rasionele besluitneming gepaard. Gewetensbesluite is daarom aangewese op die gebruik van ons gesonde verstand. Die implikasie is dat ons insigte oor sosiaal-politieke oplossings maar baie relatief is en oop is vir verandering en verbetering (Honecker 1990:142-145). Dít is tog wat Besluit 54 onderskryf. Die NHKA het op grond van talle argumente, insluitend rasionele argumente, tot die insig gekom dat sy haar nie langer aan 'n mislukte ideologie kan verpand nie. Met kettery het dit niks te make nie.

Calvyn se vriend, Philipp Melanchthon, het 'n saak beredeneer wat vir ons hier van groot belang is. Volgens hom bestaan daar sake, menings en oortuigings wat nie absolute geldigheid het nie - die sogenaamde adiaphora. Mense

13.Dit het bekend geraak dat sekere gemeentes heffings terughou en dat regspraktisyns wat lidmate van die Kerk is, dreig om regsgedinge téén die Kerk te voer sou die Kerk nie Besluit 54 herroep nie (vgl. Beukes 2011; Beeld 04 Junie 2011a:3, 08 Junie 2011b:4, 22 Junie 2011c:11). 
dink dat Melanchthon net op die relatiwiteit van morele gewetensbeslissings gewys het. Interessant genoeg het die stryd oor die adiaphora primêr oor die kerklike leer gegaan. Die stryd het in 1548 ontstaan nadat Matthias Flacius Illyricus (1520-1570) die uitspraak gemaak het dat daar 'in terme van die belydenis en (liturgiese) ergernisse nie bysake is nie' (nihil est adiaphoron in casu confessionis et scandali). Melanchthon het met 'n Latynse brief (MBW no 5409, in Kuropka 2010:123 - dit was met ander woorde nie vir publieke gebruik bedoel nie) in Oktober 1549 die kerk oortuig dat slegs sekere leersake van absolute belang is en om lewe en dood gaan. In die ander minder belangrike sake behoort daar 'matigheid en toleransie' te wees, en ' $n$ aanhoudende openbare geveg oor hierdie leeraangeleenthede is kerklik onvanpas. As gevolg van Illyricus se onophoudelike getwis oor onbelangrike leeraangeleenthede het die Lutherane besluit om hom nie kerklik te begrawe nie (vgl. Jung 2010a:112-113; Kuropka 2010:114-124).

\section{Vryheid en liefde}

Die tweede gedeelte van Luther se vryheidstese het met die vryheid van die liefde te make - die vryheid om ander te dien. Liefde as diens word moontlik gemaak deur die Christelike vryheid. Karl Barth was by uitstek die teoloog van die vryheid (Sauter 1986). Vir hom, net soos Luther, word die vryheid om ander te dien uit gehoorsaamheid aan die Eerste Gebod gebore. Dit is die gehoorsaamheid aan die Eerste Gebod wat mens bevry van ideologiese bindinge wat die diens aan die naaste aan bande lê (Van Wyk 2007). Aangesien ons egter van nature geneig is om ons harte aan 'ons afgode te hang' wat ons van die vryheid beroof om ander te dien, het Calvyn gemeen dat mens die kerklike tug moet inspan om kerkmense by die vryheid van die evangelie te hou (Weinrich 2010:80-83) ${ }^{14}$.

Een van die groot probleme met die apartheidsdenke (en die Beswaarskrif) is dat die ruimte vir liefde vir die ander baie beperk is. Die uitermatige konsentrasie op selfliefde (Smit 2010) maak gehoorsaamheid aan die liefdesgebod baie moeilik. Dit is daarom raadsaam om na Calvyn 1986:556 = Inst II, 8, 54, 10-15) te luister wat ons vermaan om nie selfliefde tot God se gebod te verhef nie:

Daaruit is dit baie duidelik dat nie die liefde vir onsself nie maar die liefde vir God en ons naaste gehoorsaamheid aan die wet beteken. Dit is ook duidelik dat iemand wat so min moontlik vir homself lewe en werk, die beste en heiligste lewe, maar dat niemand slegter en onregverdiger lewe as iemand wat slegs vir homself lewe en werk, net aan sy eie belange dink en dit soek nie.

(Calvyn 1986:556 = Inst II, 8, 54, 10-15)

Calvyn het die liefde vir die ander verstaan as die etiese verantwoordelikheid ten opsigte van menslikheid (humanitas) en billikheid (aequitas). Die Christelike menslikheid en billikheid kom vir hom tot openbaring in onder meer gemeentelike gasvryheid. In die konflik tussen die inwoners van Genève en die asielsoekers het hy in 'n preek oor 1

14.Die Status Confessionis was 'n kerklike tughandeling, met die bedoeling dat die NHKA weer sal besin oor leer en lewe en tot omkeer sal kom sodat sy weer in die Gereformeerde kerkgemeenskap opgeneem kan word (Nordholt 1983:73).
Timotheus 5:7-12 daarop gewys dat alle arm asielsoekers as 'beelddraers van God' beskou en daarom gasvry ontvang moet word. Alle asielsoekers vertoon die beeld van God en verdien daarom versorging en menslike nabyheid (Opitz [2009] 2010:236-237).

\section{Die mens as beeld van God}

Die Beswaarskrif argumenteer dat Besluit 54 neerkom op 'n leerverandering. Die leerverandering sou intree met die uitdrukking 'beeld van God in die mens' in die motiveringsgedeelte van die besluit. Die antropologie wat blykbaar agter hierdie formulering wegkruip maak die verlossingsleer oorbodig en is daarom kettery. Hierdie bydrae tot die debat fokus op die argument dat die Reformatoriese teologie met die argument sou werk dat die sondeval die beeldskap van die mens totaal vernietig het en dat hy daarom verlos moet word - en dat verder niks te sê is nie, behalwe dat Apartheid nie verwerp moet word nie.

Ek konsentreer hier op Johannes Calvyn se verstaan van die imago Dei op grond van die feit dat die Kerk van leerdwaling aangekla word. Hier is nie ruimte om aandag aan die ander reformatore ${ }^{15}$ en resente sistematiese bydraes te gee nie (vir resente sistematiese bydraes kan gekyk word na Jüngel 1980; Pannenberg 1991:203-314; Moltmann 2010:241-253 en Sauter 2011:59-94). Die teologie van Calvyn vorm tot ' $n$ groot mate die basis van die antropologie van die Hervormde belydenisskrifte. Calvyn se leer oor die beeldskap van die mens gee aan ons dus 'n goeie aanduiding oor hoe die belydenisskrifte oor hierdie saak verstaan behoort te word, en hoe nie. Dit is duidelik dat die Beswaardes hulle nie op Calvyn kan beroep vir hulle interpretasie en uitleg van die imago Dei nie. Calvyn se verstaan loop op die kardinale punte in presies die teenoorgestelde rigting.

Wat verstaan Calvyn onder die mens as beeld van God? As vertrekpunt stel hy dat 'beeld' en 'gelykenis' sinonieme is (Calvyn [1559] 1984:290-291 = Inst 1, 15, 3, 40-59) en dat hy daarom slegs van die beeld van God praat. Beeld beteken 'die uitstraling van die heerlikheid van God' in die mens ([1559] 1984:292-294 = Inst 1, 15, 4). 'Die mens is dus na die beeld van God geskep, omdat die Skepper sy eie heerlikheid soos in 'n spieël in hom wou laat sien' ([1559] 1986:620-622 = Inst 2, 12, 6). Dit is insiggewend dat Calvyn die beeldskap dan dadelik Christologies kwalifiseer. Hy lees Genesis dus vanuit die perspektief van die Nuwe Testament en nie omgekeerd, soos dit algemeen gedoen word nie. Die mens was beeld van God 'omdat hy na die voorbeeld van die toekomstige Christus gevorm was' ([1559] 1986:620 = Inst 2, 12, 6). Calvyn het by Paulus (Kol 3:10, Ef 4:24) gesien dat die hernude beeld met wysheid, geregtigheid en heiligheid te make het. 'Daaruit kan ons aflei dat die beeld van God in die begin in die verligting van die verstand en regskapenheid van die hart geleë was'

15.Die uitdrukking 'beeld van God in die mens' was ' $n$ aanvaarbare uitdrukking vir die Reformatore. As ' $n$ voorbeeld, een aanhaling uit Philipp Melanchthon ([1533] 2010) se antropologie. 'Ek bid tot U, Seun van God, Jesus Christus! U is vir on gekruisig en het weer opgestaan. $U$ is die lewende en ongeskonde beeld van die ewige Vader ... Vernuwe u ewebeeld in ons deur u lig. Leer en lei ons deur u Heilige Gees, sodat ons $u$ ewige Vader, $U$ en die Heilige Gees reg mag aanroep en vereer' (vgl. Jung 2010b:45-46 vir die volledige gebed). 
([1559] 1984:293 = Inst 1, 15, 4, 49). Hierdie beeld word nóú deur die Heilige Gees vernuwe en die gelowige moet in die lig van die voorbeeld van Jesus Christus hierna strewe.

Waar word die beeld gevind? Volgens Calvyn het die beeldskap nie net betrekking op die verhouding tussen God en mens nie, maar ook op die voortreflikhede in die mens, wat met die term 'siel' aangedui word (Van Wyk 1993:10). Die beeldskap is dus nie primêr te vinde in sy verhouding met God nie, maar in sy siel ([1559] 1984:291 = Inst 1, 15, 3, 70). Die beeld is die 'innerlike goed van die siel' ([1559] 1984:294 = Inst 1, 15, 4, 49) of die beeld is in die siel 'ingegraveer' ([1559] 1984:295 = Inst 1, 15, 5, 26). Maar, gaan hy voort:

hoewel die setel van die goddelike beeld primêr in die mens se verstand en sy hart of in sy siel en die vermoëns daarvan gesetel was, was daar tog geen deel - en selfs sy liggaam val daaronder - waarin daar nie 'n vonkie van die beeld van God geglinster het nie

(Calvyn [1559] 1984:291= Inst 1, 15, 3,78-80)

Dieselfde standpunt herhaal hy in sy Christologie ([1559] 1986:622-624 = Inst 2, 12, 7). Dit alles kom daarop neer dat Calvyn geen probleem met die uitdrukking 'die beeld van God in die mens' sou gehad het nie. Trouens - die gedagte kan by hom teruggevind word. Duidelik sien Calvyn die imago Dei nie net as iets relasioneel nie, maar ook as iets substansieel (Engel 1988:54-59; Van Wyk 1993:2). Vanselfsprekend is die beeldskap nie net iets in die mens nie, aangesien dit sy hele menswees omvat - sy liggaamlikheid en sekerlik ook sy verhoudinge.

Het die sondeval die beeldskap totaal verwoes? Calvyn gee 'n tweeledige antwoord op hierdie vraag. Aan die een kant sê hy dat die sondeval die mens radikaal en totaal aangetas het, en aan die ander kant sê hy dat daar sprake is van residua of oorblyfsels van goedheid in die mens. Hierdie tweepoligheid kom gereeld by Calvyn voor. Vir die 'totale verdorwenheid' gebruik hy terme soos uitgewis en weggevee en vir die 'nie-ten-volle korruptheid' gebruik hy terme soos misvorm, verswak, oorblyfsels van goedheid en vonkies. Hier is een voorbeeld van sy argumentasiewyse:

Hoewel ons daarom toegee dat die beeld van God nie volkome in hom tot niet gemaak en uitgewis is nie, was dit nogtans so bedorwe dat die oorblyfsels daarvan verskriklik misvorm is.

$$
\text { (Calvyn [1559] 1984:292 = Inst 1, 15, 4, 7-9, }
$$$$
\text { 1948:94-95 = Komm Gen 1:26) }
$$

Hoekom hierdie genuanseerde standpunt? Calvyn ([1559] 1986:383-385 = Inst 2, 2, 12), in aansluiting by Augustinus en Petrus Lombardus (Peters 1979:86), onderskei tussen 'natuurlike gawes' (verstand, oordeelsvermoë en wil) en 'geestelike gawes' (geloof, liefde, geregtigheid en heiligheid) - of anders gesê, tussen die bonatuurlike gawes van die lig van die geloof en die geregtigheid wat tot die hemelse lewe sal lei, en die natuurlike gawes van 'n gesonde gees (sanita mentis) en 'n opregte hart (recitudo cordis). Die natuurlike gawes is 'bederf' maar nie 'uitgeblus' nie. Die rede van die mens is nie heeltemal vernietig nie maar slegs 'verswak' en 'bedorwe'. In die bedorwe natuur van die mens 'skitter nog vonkies', en is daar nog 'brokstukkies van onverdorwenheid' (deformes ruinae; [1559] 1986:384 = Inst 2, 2, 12, 17-34). Calvyn ([1559] 1986:385-386 = Inst 2, 2, 13) onderskei verder tussen 'aardse dinge' (regering, ekonomie, wetenskappe en kunste) en 'geestelike dinge' (kennis van God, ware geregtigheid en toekomstige lewe). In aansluiting by Luther onderskei Calvyn dus duidelik tussen die mens se bestaan voor God (coram Deo) en sy bestaan voor mense (coram hominibus), tussen die mens se relasie tot God (homo theologicus) en sy bestaan binne die wêreld (homo mortalis huius vitae). Ten opsigte van die kennis van God (se liefde vir die mens), is hy 'blinder as 'n mol' ([1559] 1986:391-392 = Inst 2, 2, 18). Ten opsigte van die aardse dinge is die mens egter nie van die lig van die rede beroof nie. Die mens se natuur is nie ten volle bedorwe nie en aspekte van die beeldskap is nog in die mens herkenbaar ([1559] 1986:409-411 = Inst 2, 3, 3). Dit is hierdie reste van die beeldskap wat die mens van diere onderskei en die verwagting skep dat die mens nie teenoor ander op 'n onmenslike wyse sal optree nie ([1559] 1986:540-542 = Inst $2,8,39-40)$. Die goeie oordeel oor sake en die regte besluite oor aardse dinge, bly egter genade en voorsienigheid ([1559] 1986:435-436 = Inst 2, 4, 6). God se genade en voorsienigheid hou genadiglik die bedorwenheid van die mens in bedwang ([1559] 1986:409-411 = Inst 2, 3, 3). In ooreenstemming met die Reformatoriese onderskeiding van God se twee regimente (later ryke genoem), onderskei Calvyn dus ook in die antropologie tussen die ewige dinge voor God en die burgerlike orde tussen mense. Hierdie onderskeiding hou verband met die onderskeiding tussen die eerste en tweede tafels van die wet. Die verhouding met God en die lewe in die wêreld lê dus op twee verskillende vlakke wat nie met mekaar verwar moet word nie. Belangrik is dat vir Calvyn nie net die lewe voor God belangrik is nie, maar ook die lewe tussen en saam met ander mense (Peters 1979:85).

Kontekstuele konsekwensies: Wat wil Calvyn uiteindelik sê? Die mens is nie só verdorwe dat hy ontmens is nie, maar elke aspek van menslike lewe word deur die sonde aangetas. Die sonde het die mens nie tot ' $n$ dier verlaag nie. Alle mense bly mense en verdien om met liefde behandel te word ([1559] 1988:890-891 = Inst 3, 7, 6). Calvyn sou nie die 'teologie van haat' - wat beweer dat alle mense nie mense is nie en daarom nie liefde verdien nie - nie kon verdedig nie (Van Wyk 1993:12-13). Volgens Calvyn moet die mens, met die oorblyfsels van die reste van die beeldskap voor die aangesig van die oordelende God voortdurend tot gewetensbeslissings kom tussen goed en kwaad. Die wete dat hy deur God tot verantwoording geroep sal word op grond van sy kennis van die wet van God, hou sy gewete wakker om die soeke na reg en verkeerd nie te vergeet nie ([1559] 1984:288 = Inst 1, 15, 2, 70-80). Dus: Weens die verlies van die bonatuurlike gawes het ons Christus as ons verlosser nodig. Met die behoud van brokstukkies van ons beeldskap het die mens nie tot ' $n$ dier verlaag nie en bly hy verantwoordelik vir sy menswees en sy omgewing. Hiertoe help sy natuurlike gawes en talente, asook die algemene voorsienigheid van God en die leiding van die Heilige Gees (Peters 1979:86-88). 


\section{Imago Dei en die sosiaal-etiese konsekwensies}

Die Beswaarskrif werk met die grondtese dat daar geen band tussen teologiese antropologie en sosiale etiek is nie. Die kerk moet die boodskap van sonde en verlossing verkondig en die wêreld oorlaat aan homself. Dit is dus teologies onaanvaarbaar dat die Kerk haar negatief oor apartheid uitgelaat het. Hierdie politieke dosetisme is hoegenaamd nie met Calvyn versoenbaar nie.

Calvyn het die Reformatoriese leer oor die twee regimente wat Luther prinsipieel bedink het, verder uitgewerk en prakties geïmplementeer (Van Wyk 1996) ${ }^{16}$. Wat hier van belang is, is dat Calvyn nie net teologiese nadenke oor staats- en politieke aangeleenthede as belangrik beskou het nie, maar dat hy ook die rigting aangedui het hoe daar oor politieke toestande gedink moet word.

In die Institusie III, 19, 15 (vgl. Calvyn [1559] 1988:1074-1075) verduidelik hy die onderskeiding tussen die geestelike en burgerlike regimente. Die eerste onderrig die menslike gewete oor die vroomheid en die verering van God, en die tweede voed mense op oor die pligte van die mensdom en die burgerlike lewe. Oor die tweede regiment het die kerk tog iets te sê, ten spyte daarvan dat dít nie die kerk se werkterrein is nie. Hierdie taak word nie aan die 'sekulêre instansies' alleen oorgelaat nie. Die merkwaardige is dat die laaste hoofstuk van die Institusie (IV , 20 = Calvyn [1559] 1992:1821-1859) nie met die geestelike regiment (die eskatologie) eindig nie, maar met die burgerlike regiment (die staatswese). Vir hom was dit belangrik dat, ter wille van die kerk, die staat goed en ordelik sal funksioneer. Enkele perspektiewe is vir hierdie debat van belang.

Die hoofmelodie van Calvyn se staatsleer is Handelinge 5:29 ([1559] 1992:1858-1859 = Inst IV , 20, 32). Geen koning, regering of beleid verdien meer gehoorsaamheid as God nie. Die implikasie is dat daar nooit by één regeersisteem en maatskaplike toestand vasgehaak kan word wat nie menslikheid na behore bevorder nie. Onder geen omstandighede mag die ryk van God met 'n bepaalde politieke sisteem verwar word nie. Die kerk en haar lidmate het die plig om voortdurend krities te vra na die menswaardigheid of onmenswaardigheid binne ' $n$ bepaalde politieke bestel (Welker 2010:249). Calvyn het merkwaardig genoeg gemaan teen 'n fiksering op Europese regeringsmodelle. In die lig van sy universele kennis van politieke modelle, het hy mense aangeraai om na verskillende moontlikhede vir oplossings te kyk. Hy het kennis gehad van die verskillende kwaliteite en gevare van die onderskeie sisteme en het mense dienooreenkomstig geadviseer ([1559] 1992:1829-1831 = Inst IV , 20, 8). Hy was 'n voorstander van magsbalans, matigheid, beperkings, en relatiewe voordele en nadele. Die belangrike balans tussen verskillende instellings (soos dié tussen die staat en die regswese - [1559] 1992:1857 = Inst IV, 20, 31)

16.Luther verteenwoordig die eerste generasie van Hervormers terwyl Calvyn die tweede generasie verteenwoordig. Calvyn het Luther nie verdedig deur hom te huther se konteks was dié van 'n klooster te dalvyn se konteks dié val konteks. luther se konteks was die van 'n klooster en Caluyn se konteks dié van die stad. Getrou aan Luther se grondgedagte, het Calvyn bloot die verband tussen vertikaal en horisontaal verder uitgewerk (Weinrich 2010:84-86). Ons leef 50 jaar n Republiekwording. Ons kan tog nie vasgevang bly binne daardie konteks nie. was vir hom van groot belang. Daarom was 'n ideologiese verstaan van die staatswese vir hom 'n ondenkbaarheid. Vir hom was daar altyd ruimte vir verbetering, behalwe as God 'n skuldbelaaide volk met ' $n$ bose regering wil straf ([1559] 1992:1855 = Inst IV, 20, 29). 'n Onregsisteem kan nie tot die wil van God verklaar word nie, terwyl positiewe sosiaalmaatskaplike tendense nog nie die ryk van God is nie. Elke sisteem moet beoordeel word aan die hand van twee kriteria, (1) of dit die verering van God bevorder en (2) of dit die swakkes beskerm en bydra tot die openbare orde en vrede.

Calvyn het geweet dat die Christologiese etiek moeilik in staatkundige wette omgeskakel kan word. Nogtans was hy 'n voorstander van 'navolgingsetiek' met die hoop dat lidmate se invloed tot in die maatskaplike lewe kon deursuur. Ten spyte van sy ondersteuning van Luther se onderskeiding van wet en evangelie, was hy ook ten gunste van 'n derde gebruik van die wet as riglyn vir die publieke lewe (tertius usus legis). Ek noem één ter saaklike voorbeeld: Calvyn het by Paulus (1 Kor 6:1-11) geleer dat 'n 'hofwoede' nie by Christene pas nie. In die kerk is ons veronderstel om op 'n nie-juridiese wyse met mekaar om te gaan. Hierdie welwillendheid moet uitkring na die openbare lewe. Die burgery moet beïnvloed word om ook in liefde en vriendskap, sonder wraaksug en regsug, teenoor mekaar op te tree (Inst IV, 20, 18). Hierdie 'koeler omgang' met konflik, gebore uit 'n liefde-gedrewe kerkreg, moet deurwerk in die reg en (kerk)politiek tot groter roem van God (ad majorem Dei gloriam).

\section{Die probleem van reg en geregtigheid}

Die kerk het nie die primêre verantwoordelikheid om wette te skryf en beleide te bedink nie aangesien haar opdrag dié van die liefde is. Liefde mond egter uit in 'geregtigheid' (Pannenberg 1996:73-93). Wêreldlike geregtigheid het natuurlik grense en perke en vanselfsprekend vind Goddelike geregtigheid nie sy voortsetting in ons strewe na geregtigheid nie. Wat God egter wel van ons verwag is arbeid aan 'n mensliker wêreld. Geregverdigde sondaars moet daarna trag om glimpsies van God se geregtigheid te laat realiseer, welwetende dat ons geregtigheid nie as voortsetting van God se geregtigheid misverstaan mag word nie en dat elke geregtigheidstrewe in die erediens eindig met die bede om die vergewing van skuld (Jüngel [1998] 1999:221-234). In die lig hiervan het Calvyn byvoorbeeld vir meer regverdige lone gepleit (vgl. Nyomi 2010:121). Die Calvinistiese teoloë se betrokkenheid by geregtigheidsvraagstukke is gegrond in die sentrale leerstukke van die Reformatoriese teologie (Hunzinger 2009:224-230; Moltmann 2010:27-43). Weereens: Menslike geregtigheid is tweeduidig en word nooit evangelie nie. Die bose bly dus, maar met die wete dat dit nie vir ewig sal bly nie (Bayer 1995:296, 202). Hierdie eskatologiese verwagting is iets anders as die verlange na verlossing uit hierdie bose wêreld. Hoe gebrekkig ons geregtigheidspogings ook mag wees, ons kan alles nie maar laat en laat vaar nie. God self doen dit nie. As 'n daad van genade oordeel God ons. Sou God nie ook regter wees nie, sou Hy onbarmhartig wees deurdat Hy die bose sy gang laat gaan. Ons as Christene behoort duidelike ongeregtigheid minstens af te wys - sonder om te pretendeer dat die koninkryk daardeur sal kom. 
Die liefde mond nie net uit in die geregtigheid nie, maar ook in die reg (Moltmann 2010:189-210; Pannenberg [1978] 2004a, [1992] 2004b). Die beter reg, die reg gedrewe deur die liefde, bevorder die ander een se reg. Hiervoor kan die kerk maar net pleit, aangesien sy dit nie kan afdwing nie. Nogtans mag sy sekerlik krities vra of bepaalde wette, beleide en ideologieë die reg van ander respekteer en bevorder al dan nie (Jüngel 1990b:361-364). Dít is tog sekerlik nie 'bevrydingsteologie' nie. Om vas te steek by die ideologiese denke van die verlede (Beswaarskrif 2010:5), help niemand nie. Die politieke landskap het reeds dramaties verander. Dit het daarom tyd geword om aan te beweeg. Daar is nuwe uitdagings wat op ons wag in hierdie pluralistiese land.

\section{Laaste gedagtes}

Die Beswaardes en hulle simpatisante (vgl. onder andere Brecher 2011) is gekant teen verandering en vernuwing ten opsigte van 'n sosiaal-etiese oriëntasie. Alles moet soos 'in die goeie ou dae' bly. Geen verruiming van teologiese denke word geduld nie - met die pretensie dat hierdie houding op die bewaring van die Reformatoriese tradisie neerkom. Die Hervormde tradisie funksioneer onder die bekende maar oorsprongsduister spreuk "n Hervormde kerk hervorm aanhoudend' (ecclesia Reformata et semper reformanda). Die spreuk moet eerder lui 'die Hervormde teologie hervorm voortdurend' (theologia Reformata et semper reformanda) (Moltmann 1999) ${ }^{17}$. Wat hiermee bedoel en nie bedoel word nie, kan uit Luther en Calvyn se teologiese metodes geleer word.

Volgens Luther is teologie hoogstens 'n antwoord op dít wat mens in die prediking gehoor het. Teologie is net moontlik as iemand persoonlik aangespreek word deur die evangelie soos dit saamgevat word in die boodskap van die regverdiging. Die persoonlike aangespreektheid konstitueer 'n teoloog tot teoloog. Die feit dat iemand deur die evangelie aangespreek word, is en bly genade van die Gees (gratia Spiritus). Daar is egter, ook vir die teoloog, aanhoudende aanvegting (tentatio). Elkeen se geloof word beproef en uitgedaag. Die positiewe ervaring met die geloof (experientia) laat jou egter voortgaan met jou taak. Die ervarings met die geloofservarings is die dryfveer van teologie. Om hierdie rede beskryf Luther teologie nie as 'wetenskap' nie, maar as 'wysheid', gegrond op die geskiedenis van geloofservarings. Teologie is vir Luther ervaringswysheid (sapientia experimentalis), 'n wysheid wat ontwikkel deur die loop van tyd. 'n Teoloog moet wakker wees vir die geleentheid (occasio) wat hy voortdurend kry om die evangelie outentiek in nuwe situasies te verwoord. Dít is net moontlik deur sorgvuldige bestudering van die Bybelse tekste (sedula lectio). Teologie is eintlik maar net eksegese, maar dan die eksegese van tekste in samehang met die hele Bybelse boodskap, met die hulp van die kennis en beoefening van die wetenskappe. Sonder aanhoudende gebed (oratio) en teksmeditasie (meditatio) is regte eksegese egter nie moontlik nie (Bayer 1994:35-126, 2003:15-34). Die implikasie van

17. Moltmann self weet nie waar die spreuk vandaan kom nie. Körtner (2010:79) meen die uitspraak kan dalk na Jodocus van Lodenstein (1620-1677) teruggevoer word. Dit is ook nie seker hoe die spreuk oorspronklik gelui het nie. Beintker (2010:156) vermoed die volgende formulering: 'die [volgens God se Woord] Hervormde kerk is veronderstel om altyd weer te hervorm.' hierdie benadering is dat ' $n$ mens voortdurend besig sal bly met pogings om die evangelie in nuwe situasies te verwoord. 'n Kerk kan daarom ook nooit dink dat sy klaar gepraat het nie. Haar vorige besluite kan nie ewige geldigheid hê nie en daarom is dit totaal vreemd dat mense kan argumenteer dat die kerk nie van standpunt mag verander nie. In 'n Reformatoriese kerk word daar altyd, aan die hand van die Skrif, weer gedink en gepraat.

Volgens Calvyn begin teologie by die kerk as die leerskool van God (schola Dei) waar die Woord bestudeer word ter wille van die opbou van die gemeente. Korrekte kerklike eksegese kan nie geskied sonder inagneming van die kernelemente van die tradisie soos die Triniteitsleer nie. Teologie as Skrifuitleg het die bedoeling om die Bybelse boodskap lewend te maak vir die eie tyd en omstandighede, met die verwagting dat die Woord aanvaar en gehoorsaam sal word. In hierdie proses word die tradisie vernuwe - en somtyds selfs verander - ter wille van die evangelie. In sy geval kon hy nie bly staan by die Roomse leertradisie nie. Vir Calvyn was dit duidelik; indien 'n bepaalde tradisie die gehoorsaamheid aan die Woord strem, moet dit reggestel word. Binne hierdie tipe teologie gaan dit nooit om vernuwing ter wille van vernuwing nie of verstardheid uit beginsel nie. Tradisie is nie ' $n$ heilige saak nie en kan en moet verander indien dit die opbou van die kerk nie dien nie (Haas [2009] 2010:33-37; Holder 2008:387-389).

Die weiering om Besluit 54 te duld het ook te make met die feit dat die Beswaardes politiek as geloof verstaan. Reformatories is dít gewoon verkeerd. Die (aanvaarbare) politieke gebruik van die wet word hier omvorm tot die (onaanvaarbare) politieke gebruik van die evangelie (Ebeling 1982). Deur 'n politieke saak 'n dogmatiese saak te maak, dui daarop dat ons in die Beswaarskrif te make het met die 'instrumentalisering van die geloof' (Jüngel 1990b:348) wat tog nie versoenbaar is met die Reformatoriese teologie nie. Geloof in God is hier nie geloof ter wille van geloof nie, maar geloof ter wille van 'n sosiaal-etiese ideaal. Die illusie wat geskep word dat diegene wat die apartheidsideaal probeer lewe gee, met die regte leer besig is, en dat diegene wat van apartheid afskeid wil neem, met kettery besig is, moet tot 'n einde kom.

Die beswaar teen Besluit 54 het uiteindelik ten doel om te keer dat die NHKA 'n poging sal aanwend om ekumeniese bande te herstel ${ }^{18}$. Dit is onbegryplik dat mense wat voorgee om die Reformatoriese teologie te beskerm, 'n totale vrees vir en afsku in die ekumene ontwikkel het. Die emosionele tirade teen die ekumene het met Calvyn, as die man van die ekumene, niks te make nie (vgl. Van Wyk 2010). Distansie van die ekumene is distansie van Calvyn. Sy ekklesiologie getuig van 'n verstaan van die kerk as die gemeenskap van gelowiges. In hierdie gemeenskap is daar nie net gemeenskap met God nie, maar ook gemeenskap met ander gelowiges reg oor die wêreld. Hervormde gelowiges, gemeentes en kerke leef nie in afsondering nie (Beintker 2010; Birmelé

18.Vanselfsprekend (Die Hervormer April 2011a:7) wou die NHKA met Besluit 54 ' $\mathrm{n}$ tree nader gee aan die ekumene. Dit was ook te wagte dat mense uit die dampkring van die Beswaarskrif hierteen kapsie sal maak (vgl. onder andere Engelbrecht 2011; Van den Berg 2011). 
2010). Wie nie met geloofsgenote gemeenskap wil hê nie, nie vir hulle voorbidding wil doen nie, hulle nie in nood wil help nie en in vrees vir hulle lewe, het met die Calvinistiese gees niks te make nie. Ons weet mos: 'Wie liefhet, vrees nie' (1 Joh 4:18).

\section{Erkennings Mededingende belange}

Die outeur verklaar dat hy geen finansiële of persoonlike verbintenis het met enige party wat hom nadelig kon beïnvloed in die skryf van hierdie artikel.

\section{Literatuurverwysings}

' 3 broers wil Hervormde Kerk hof toe sleep oor apartheid', Beeld, 04 Junie, 2011a, p. 3.

Bayer, O., 1984, Aus Glauben leben: Über Rechtfertigung und Heiligung, Calwer Verlag Stuttgart.

Bayer, O., 1994, Theologie, Mohn, Gütersloh.

Bayer, O., 1995, Freiheit als Antwort: Zur theologischen Ethik, Mohr, Tübingen.

Bayer, O., 2003, Martin Luthers Theologie: Eine Vergegenwärtigung, Mohr, Tübingen.

'Besluit oor die Beswaarskrif', Die Hervormer, April, 2011a, p. 7.

'Buitengewone sitting van die AKV', Die Hervormer, Augustus, 2011b, p. 3.

'Beswaardes: "Begin proses van voor af"', Beeld, 08 Junie, 2011b, p. 4.

Beintker, M., 2010, 'Calvins theologisches Denken als ökumenische Herausforderung', in M. Weinrich \& U. Möller (Hrsg.), Calvin heute: Impulse der reformierten Theologie für die Zukunft der Kirche, 2. Aufl., pp. 151-167, Neukirchener Verlag, Neukirchen-Vluyn.

Beukes, D., 2011, 'Beswaarskrif oor Besluit 54', Die Hervormer, Januarie, p. 3.

Birmelé, A., 2010, 'Calvins Kirchenverständnis und die heutigen ökumenischen Herausforderungen', in M. Weinrich \& U. Möller (Hrsg.), Calvin heute: Impulse der reformierten Theologie für die Zukunft der Kirche, 2. Aufl., pp. 103-118, Neukirchener Verlag, Neukirchen-Vluyn.

Botha, S.J. (red.), 1989, Belydende volkskerk, KITAL, Pretoria

Brecher, L., 2011, 'Oor die herderlike skrywe', Die Hervormer, Maart, p. 7.

Bühler, P., 2009, 'Der Mensch vor der Aufgabe ethischer Verantwortung: Anthropologie und Ethik in Luthers Genesisvorlesung', Lutherjahrbuch 76, 57-76.

Burgess, J., 2009, 'Justification and sanctification: Implications for church life today' in M. Weinrich \& J. Burgess (eds.), What is justification about? Reformed contributions to an ecumenical theme, pp. 57-87, Eerdmans, Grand Rapids, MI.

Busch, E., 2010, Drawn to freedom: Christian faith today in conversation with the Heidelberg Catechism, transl. W. Rader, Eerdmans, Grand Rapids, MI.

Calvyn J., 1948, Commentaries on the book of Genesis, vol. 1, transl. J. King, Eerdmans, Grand Rapids, MI.

Calvyn, J., [1559] 1984, Institusie van die Christelike Godsdiens 1559, Boek 1 Afrikaanse vertaling deur $\mathrm{H}$. Simpson, $\mathrm{CJBF}$, Potchefstroom.

Calvyn, J., [1559] 1986, Institusie van die Christelike Godsdiens 1559, Boek 2, Afrikaanse vertaling deur $\mathrm{H}$. Simpson, CJBF, Potchefstroom.

Calvyn, J., [1559] 1988, Institusie van die Christelike Godsdiens 1559, Boek 3, Afrikaanse vertaling deur $\mathrm{H}$. Simpson, CJBF, Potchefstroom.

Calvyn, J., [1559] 1992, Institusie van die Christelike Godsdiens 1559, Boek 4, Afrikaanse vertaling deur $\mathrm{H}$. Simpson, CJBF, Potchefstroom.

Ebeling, G.,1972, 'Leitsätze zur Zweireichelehre', Zeitschrift für Theologie und Kirche 69(3), 331-349.

Ebeling, G., 1982, 'Usus politicus legis - usus politicus evangelii', Zeitschrift für Theologie und Kirche 79(3), 323-348.

Ebeling, G., 1983, 'Die Toleranz Gottes und die Toleranz der Vernunft', in Umgang mit Luther, pp. 101-130, Mohr, Tübingen.

Engel, M., 1988, John Calvin's Perspectival Anthropology, Scholars Press, Atlanta, GA. Engelbrecht, K., 2011, 'Ons Kerk sal ernstig moet besin', Die Hervormer, Maart, p. 7.

Graf, F.W., 2011, Kirchendämmerung: Wie die Kirchen unser Vertrauen verspielen, $\mathrm{CH}$ Beck, München.

Haas, G., [2009] 2010, 'Calvin als Vorbild für eine theologische Schriftauslegung: Verdeutlicht anhand seiner Exegese von $1 \mathrm{Tim} 4,1-5$ ', in M. Weinrich \& U. Möller (Hrsg.), Calvin heute: Impulse der reformierten Theologie für die Zukunft der (Hrsg.), Calvin heute: Impulse der reformierten Theologie für die
Kirche, 2. Aufl., pp. 19-39, Neukirchener Verlag, Neukirchen-Vluyn.

'Herderlike Skrywe van die Kommissie van die AKV', Die Hervormer, Maart, 2011c, p. 1.

'Hervormde Kerk: "Daar is geluister"', Beeld, 22 Junie, 2011c, p. 11.
Holder, R.W., 2008, 'Tradition und Erneuerung', in H. Selderhuis (Hrsg.), Calvin Handbuch, pp. 379-389, Mohr, Tübingen.

Honecker, M., 1990, Einführung in die Theologische Ethik: Grundlage und Grundbegriffe, De Gruyter, Berlin.

Honecker, H., 1995, Grundriß der Sozialethik, De Gruyter, Berlin.

Hunzinger, G., 2009, 'Justification and justice: Towards an evangelical social ethic' in M. Weinrich \& J. Burgess (eds.), What is justification about? Reformed contributions to an ecumenical theme, pp. 207-230, Eerdmans, Grand Rapids, MI.

Jung, M., 2010a, Philipp Melanchthon und seine Zeit, Vandenhoeck, Göttingen.

Jung, M., (Hrsg.) 2010b, Ich rufe zu dir: Gebete des Reformators Philipp Melanchthon, Hansisches Druck- und Verlagshaus, Frankfurt.

Jüngel, E., 1980, 'Der Gott entsprechende Mensch: Bemerkungen zur Gottebenbildlichkeit des Menschen als Grundfigur theologischer Anthropologie', in Entsprechungen: Gott - Wahrheit - Mensch: Theologische Erörterungen II., pp. in Entsprechungen: Gott - Wat
290-317, Kaiser, München.

Jüngel, E., 1990a, 'Der menschliche Mensch: Die Bedeutung der reformatorischen Unterscheidung der Person von ihren Werken für das Selbstverständnis des neuzeitlichen Menschen', in Wertlose Wahrheit: Zur Identität und Relevanz neuzeitlichen Menschen', in Wertlose Wahrheit: Zur Identitat und Relevanz
des christlichen Glaubens: Theologische Erörterungen III, pp. 194-213, Kaiser, des christlichen Glaubens:
München. (BevTh 107.).

Jüngel, E., 1990b, 'Leben aus Gerechtigkeit: Gottes Handeln - menschliches Tun', in Wertlose Wahrheit: Zur Identität und Relevanz des christlichen Glaubens: in Wertlose Wahrheit: Zur Identität und Relevanz des christlichen Glauben
Theologische Erörterungen III, pp. 346-364, Kaiser, München. (BevTh 107.).

Jüngel, E., [1998] 1999, Das Evangelium von der Rechtfertigung des Gottlosen als Zentrum des christlichen Glaubens: Eine theologische Studie in ökumenischer Absicht: 3. verbesserte Aufl., Mohr, Tübingen.

Jüngel, E., 2000, Zur Freiheit eines Christenmenschen: Eine Erinnerung an Luthers Schrift, in Indikative der Gnade - Imperative der Freiheit: Theologische Erörterungen IV, pp. 84-160, Mohr, Tübingen.

Körtner, U., 2010, Reformatorische Theologie im 21: Jahrhundert, Theologischer Verlag, Zürich. (Theologische Studien. Neue Folge. Bd 1.)

Kuropka, N., 2010, Melanchthon, Mohr, Tübingen. (UTB Profile.)

Luther, M 1520a, Von der Freiheit eines Christenmenschen, in WA 7, 20-38.

Luther, M 1520b, Tractatus de libertate christiana, in WA 7, 39-57.

Luther, M., 1883vv, Luthers Werke: Kritische Gesamtausgabe, 67 Vol, Weimarer Ausgabe $=W A$

Luther, M., 1883vv, Luthers Werke: Kritische Gesamtausgabe: Tischreden, 6 Vol, Weimarer Ausgabe = WA Tr.

MacCulloch, D., 2009, Christianity: The first three thousand years, Viking (Penguin Group), New York, NY.

Melanchthon, P., [1553] 2010, ‘Gottes Bild im Menschen: Zerstörung und Wiederherstellung (Liber de anima)', in Glaube und Bildung: Texte zum christlichen Humanismus, pp. 80-89, Hg v G. Schmidt, Reclam, Stuttgart.

Moltmann, J., 1999, 'Theologia Reformata et semper reformanda', in D. Willis \& M. Welker (eds.), Toward the future of Reformed Theology: Tasks, Topics, Traditions, pp. 120-135, Eerdmans, Grand Rapids, MI.

Moltmann, J., 2010, Ethik der Hoffnung, Gütersloher Verlagshaus, Gütersloh.

Nederduitsch Hervormde Kerk van Afrika, 1973, Herderlike Skrywe van die Algemene kerkvergadering, in D.J.C. van Wyk (red.), 1978, Stemme uit die verlede 1 Volkereverhoudings in Suid-Afrika, pp. 258-272, HAUM, Pretoria.

Nederduitsch Hervormde Kerk van Afrika, 1985, Kerk en Wêreld 2000, KITAL, Pretoria.

Nederduitsch Hervormde Kerk van Afrika, 1990, Kerk en Politiek: Herderlike Skrywe, uitgestuur deur die Kommissie van die AKV, KITAL, Pretoria.

Nederduitsch Hervormde Kerk van Afrika, 2010, 'Besluitebundel', 69ste Algemene Kerkvergadering vanaf Sondag 26 September 2010.

Nordholt, H-H. (zus), 1983, Apartheid und Reformierte Kirche: Dokumente eines Konflikts, Neukirchener Verlag, Neukirchen-Vluyn.

Nyomi, S., 2010, 'Der Reformierte Weltbund und das Erbe Calvins', in M. Weinrich \& U. Möller (Hrsg.), Calvin heute: Impulse der reformierten Theologie für die \&ukunft der Kirche, 2. Aufl., pp. 119-130, Neukirchener Verlag, Neukirchen-Vluyn. Zukunft der Kirche, 2. Aufl., pp. 119-130, Neukirchener Verlag, Neukirchen-Vluyn.
Beswaarskrif, 2010, Vergadering,Gereformeerde Kerk, Meyerspark, Pretoria, 13

Opitz, P., [2009] 2010, 'Calvins Interpretation der Kirche als “Gemeinschaft der Heiligen” als 'Herausforderung und Chance für "reformierte" Kirchen der Gegenwart', in M. Weinrich \& U. Möller (Hrsg.), Calvin heute: Impulse der reformierten Theologie für die Zukunft der Kirche, 2. Aufl., pp.225-242, Neukirchener Verlag, NeukirchenVluyn.

Pannenberg, W., 1991, Systematische Theologie: Band 2.,Vandenhoeck, Göttingen.

Pannenberg, W., 1996, Grundlagen der Ethik: Philosophisch-theologische Perspektiven, Vandenhoeck, Göttingen. (Kleine Vandenhoeck-Reihe 1577.)

Pannenberg, W., [1978] 2004a, 'Christliche Rechtsbegründung', in Beiträge zur Ethik, pp. 38-54, Vandenhoeck, Göttingen.

Pannenberg, W., [1992] 2004b, 'Leben in Gerechtigkeit', in Beiträge zur Ethik, pp. 202-212, Vandenhoeck, Göttingen.

Peters, A., 1979, Der Mensch, Mohn, Gütersloh. 'Redes waarom die Kommissie van die AKV besluit het om ' $n$ buitengewone sitting van die AKV te hou', Die Hervormer, Augustus, 2011d, p. 4 
Sauter, G., 1982, Was heißt nach Sinn fragen?: Eine theologisch-philosophische Orientierung, Kaiser, München.

Sauter, G., 1986, '“Freiheit" als theologische und politische Kategorie', in Bekenntnis, Widerstand, Martyrium, Hrsg v G. Besier und G. Ringhausen, pp. 148-165, Vandenhoeck, Göttingen.

Sauter, G., 2011, Das verborgene Leben: Eine theologische Anthropologie, Gütersloher Verlagshaus, Gütersloh.

Selderhuis, H. (Hrsg.), 2008, Calvin Handbuch, Mohr, Tübingen.

Smit, D., 2010, 'Eigenliebe - Calvin und Calvinismus als Fundament sozialen Lebens', in M. Weinrich \& U. Möller (Hrsg.), Calvin heute: Impulse der reformierten Theologie für die Zukunft der Kirche, 2. Aufl., pp. 187-211, Neukirchener Verlag, NeukirchenVluyn.

Van den Berg, V., 2011, 'Die Kerk se besluit oor apartheid', Die Hervormer, Augustus, p. 6.

Van der Westhuizen, H.G., 1981, Volkskerk en sending, HAUM, Pretoria.

Van Wyk, D.J.C., 1985, Artikel III van die Kerkwet van die Nederduitsch Hervormde Kerk van Afrika: 'n Verantwoording, KITAL, Pretoria.

Van Wyk, I.W.C., 1994a, 'Nog steeds geslote eredienste? Deel 1', HTS Teologiese Studies/Theological Studies 50(3), 755-779.

Van Wyk, I.W.C., 1994b, 'Nog steeds geslote eredienste? Deel II', HTS Teologiese Studies/Theological Studies 50(4), 1070-1093.
Van Wyk, I.W.C., 1996, 'Het die kerk 'n politieke verantwoordelikheid: Oor die noodwendigheid en grense van die "twee-ryke-leer"', HTS Teologiese Studies/ Theological Studies 52(4), 765-799.

Van Wyk, I.W.C., 2007, "'God and the gods": Faith and human-made idols in the theology of Karl Barth', HTS Teologiese Studies/Theological Studies 63(4), 1587-1612.

Van Wyk, I.W.C. 2010, 'Calvin, Luther and church unity', In die Skriflig 44, suppl. 3 215-231.

Van Wyk, J.H., 1993, 'Homo Dei: 'n Prinsipiële besinning oor enkele mensbeskouings, waaronder dié van Calvyn', In die Skriflig 27, suppl. 1

Vroom, H., 2009, “"Meaning" as a replacement for "justification"', in M. Weinrich \& J. Burgess (eds.), What is justification about? Reformed contributions to an ecumenical theme, pp. 248-261, Eerdmans, Grand Rapids, MI.

Weinrich, M., 2010, 'Unbequeme, weil konsequente Theologie: Johannes Calvin und Karl Barth', in M. Weinrich \& U. Möller (Hrsg.), Calvin heute: Impulse der reformierten Theologie für die Zukunft der Kirche, 2. Aufl., pp. 79-95, Neukirchener Verlag, Neukirchen-Vluyn.

Welker, M., 2010, 'Calvins Lehre vom "bürgerlichen Regiment" Ihre Orientierungskraft in Pluralismus und Globalisierung', in M. Weinrich \& U. Möller (Hrsg.), Calvin heute: Impulse der reformierten Theologie für die Zukunft der Kirche, 2. Aufl., pp. 243-252, Neukirchener Verlag, Neukirchen-Vluyn.

Wolf, E., 1975, 'Das Problem der "Imago Dei"', in Sozialethik: Theologische Grundfragen, pp. 27-43, Vandenhoeck, Göttingen. 